\title{
How Do Biological and Functional Diversity Change in Invaded Tropical Marine Rocky Reef Communities?
}

\author{
Larissa M. Pires-Teixeira ${ }^{1}$, Vinicius Neres-Lima ${ }^{2}$ (D) and Joel C. Creed ${ }^{2,3, *(D)}$ \\ 1 Programa de Pós-Graduação em Ecologia e Evolução, Universidade do Estado do Rio de Janeiro, \\ Rua Francisco Xavier 524, PHLC, sala 220, Rio de Janeiro 20550-900, RJ, Brazil; larissamarques@ymail.com \\ 2 Departamento de Ecologia, IBRAG, Universidade do Estado do Rio de Janeiro, Rua Francisco Xavier 524, \\ PHLC, sala 220, Rio de Janeiro 20559-900, RJ, Brazil; vinicius.lima.eco@gmail.com \\ 3 Coral-Sol Research, Technological Development and Innovation Network, Instituto Brasileiro de Biodiversidade, \\ Rio de Janeiro 20031-203, RJ, Brazil \\ * Correspondence: jcreed@uerj.br
}

Citation: Pires-Teixeira, L.M.;

Neres-Lima, V.; Creed, J.C. How Do Biological and Functional Diversity Change in Invaded Tropical Marine Rocky Reef Communities?. Diversity 2021, 13, 353. https://doi.org/ $10.3390 / \mathrm{d} 13080353$

Academic Editor: Bert W. Hoeksema

Received: 6 July 2021

Accepted: 28 July 2021

Published: 31 July 2021

Publisher's Note: MDPI stays neutral with regard to jurisdictional claims in published maps and institutional affiliations.

\begin{abstract}
Evidence so far shows that most alien species (AS) have negative impacts on native biodiversity and are changing biodiversity in almost all environments. Here, we study eight rocky shores at four sites containing reefs with invaded communities and other not-invaded (control) communities, to evaluate the effects of four marine invasive species on biological and functional diversity. We used the adjustment and selection approach of species abundance distribution models (SAD), taxonomic diversity indices and functional diversity indices based on hierarchical grouping matrices (FD-Functional Diversity). In addition to comparing invaded and not-invaded communities, we also performed the same analysis, but removed the invaders (AS removed) from the matrices. The geometric-series model was best adjusted to the majority of communities. The diversity indices suggest that the taxonomic diversity is lower in invaded communities, while the functional diversity indices suggest a change in the functional space of invaded and not-invaded communities, with a greater amount of functional space filled by species in the not-invaded communities. Taxonomic and functional diversity indices were successful in identifying processes that determine the biological diversity of invaded communities, as they seem to obey a pattern that reflects the reduced diversity of invaded communities.
\end{abstract}

Keywords: diversity indices; functional diversity; invasive; alien species; rank abundance plots; species abundance distribution models

\section{Introduction}

The introduction of new species into a new habitat represents a change and adjustment in the pre-existing state of the receiving community. These changes can occur at different intensities and affect one or more species that already make up part of the receptor community [1]. Alien species (AS) can transform marine environments, displacing native species, changing community structure and food webs, as well as impacting the dynamics of nutrients and sedimentation rates [2]. In the marine environment the number of documented biological invasions is increasing in the tropical southwest Atlantic Ocean [3], which reflects a worldwide trend in marine ecosystems [4], and the evidence shows that most AS have negative impacts on native biodiversity and human well-being, and are changing the biodiversity of almost all environments [5-7].

Native and AS often have different biological characteristics and interactions with the community, for example chemical defenses or the high reproductive output of the AS or escape from predators within the new community. Such factors can favor their dominance in the community invaded by AS, as they become more abundant than the other species [8]. The abundance of a species, at least to some extent, reflects its success in competing for limited resources [9], so the effects of an AS will increase with its abundance and vary 
with its functional attributes. The arrival of a new species may bring with it traits which are novel to the ecosystem as well as increase species richness (always by one, at least initially), so the establishment of AS in the community can change species and functional diversity [7,10-12].

A new AS can establish itself in the receptor community by occupying a different empty niche, using different resources (the Empty Niche Hypotheses [13]), with minimal competition [14-18]. In contrast, if an AS is functionally similar to the species already existing in the invaded community, they may compete with the resident species of the community (Biotic Resistance/Diversity-Invasibility Hypotheses $[19,20])$. Both processes result in changes in the functional diversity of a community after the invasion [21-24].

Here, we used wave-protected shallow subtidal tropical rocky shore benthic communities as models. Typically, such communities are highly diverse, highly productive (including symbiotic autotrophic organisms such as corals) and space may be limiting, resulting in competition between sessile autotrophic and heterotrophic species. Under this scenario we would predict that for a species to have successfully established and invaded it will dominate and displace native species. Assuming that the abundance of a species is most often a reflection of its success in competing for limited resources $[9,25]$, we tested the hypothesis that invaded communities reflect a pattern of species abundance described by models that fit communities with less equitability (e.g., Geometric Series Model). Considering that functional diversity indices have the potential to reveal the processes of assembling the community [26], we also tested the hypothesis that invaded communities present a smaller proportion of functional space traits (functional richness, FRic), overuse of resources, and thus a less even distribution of abundance in functional space traits (functional evenness, FEve) and species loss associated with a decrease in the range of characteristic values $[27,28]$.

In order to test these hypotheses, we investigated (1) the biological and functional diversity of invaded rocky shore communities using the adjustment and selection approach of species abundance distribution (SAD) models and (2) the structure and function of communities using functional diversity indexes based on hierarchical grouping matrices (FD-Functional Diversity). We also (3) assess the effectiveness of using these parameters in evaluating the impact of AS on rocky shore communities.

\section{Materials and Methods}

We conducted the present study at four different shallow subtidal tropical rocky shore locations along about $280 \mathrm{~km}$ of the coast of the state of Rio de Janeiro, Brazil (Southwest Atlantic; Figure 1), a region which has received multiple invasions [3]. We compared community composition and structure of invaded and not-invaded communities at each site (hereby termed invasion state).

\subsection{Study Sites and Species \\ 2.1.1. Caulerpa scalpelliformis at Praia da Baleia (PB)}

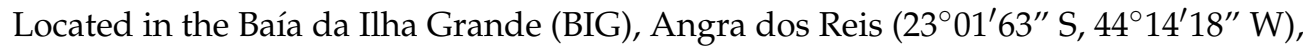
this wave-protected site has shallow $(<5 \mathrm{~m})$ waters where rocky reefs intermingle with sandy patches. Introduced in 2001, the green alga Caulerpa scalpelliformis is considered an AS at this site [29-31]. The species is widely distributed in tropical and sub-tropical waters in the Red Sea, Indian and Pacific Oceans, Caribbean Sea and Atlantic Ocean (Atlantic Islands, Western Atlantic and South America from Venezuela south to Espírito Santo State, Brazil) [30]. It is considered non-native in the Mediterranean Sea and in Brazil at the studied location due to its disjoint distribution in a very well-studied region (Rio de Janeiro) [31] (Figure 2A). At this site it is able to grow both in the sand and on isolated boulders. Although access to PB is restricted by a private condominium and a steep path, the beach often receives pleasure craft and commercial fishing boats due to its protected location. Among the possible vectors of introduction and dispersal of this species are shipping (fouling anchors and fishing gear on boats which use the site for fishing and 
recreational boating) and the aquarium trade (irregular disposal of aquarium species by commercial traders or aquarists) [31].

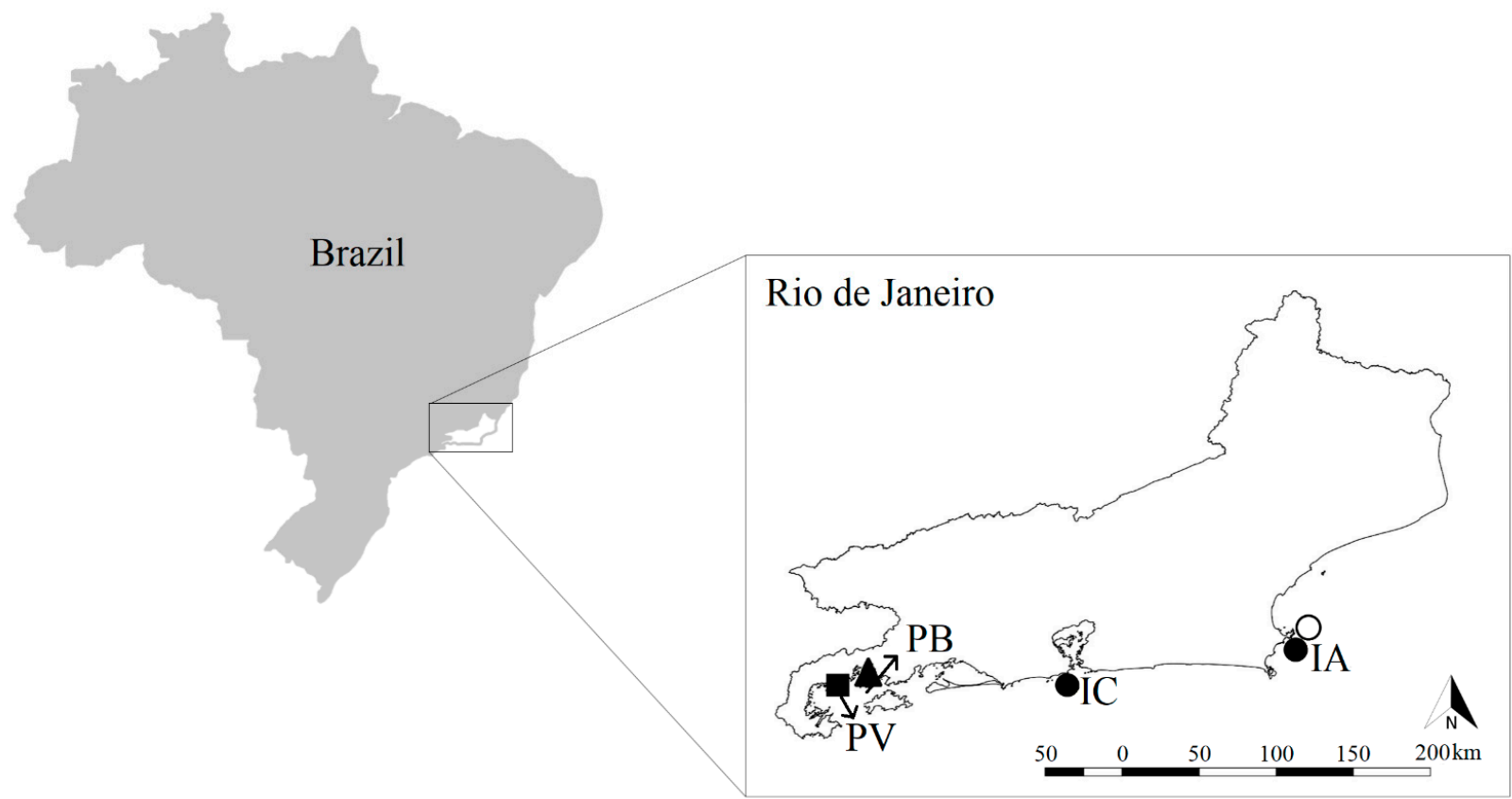

Figure 1. Map of the four study sites along the coast of the state of Rio de Janeiro, Brazil and their respective alien species. $\mathrm{cs}=$ green alga Caulerpa scalpelliformis $\mathbf{\Lambda}, \mathrm{s}=$ soft coral Sansibia sp. $\mathbf{\square}, \mathrm{tt}=$ azooxantellated coral Tubastraea tagusensis $\bullet$, tc = azooxantellated coral Tubastraea coccinea $\bigcirc, \mathrm{PV}=$ Praia Vermelha, PB = Praia da Baleia, IC = Ilha Comprida and IA = Ilha de Âncora.

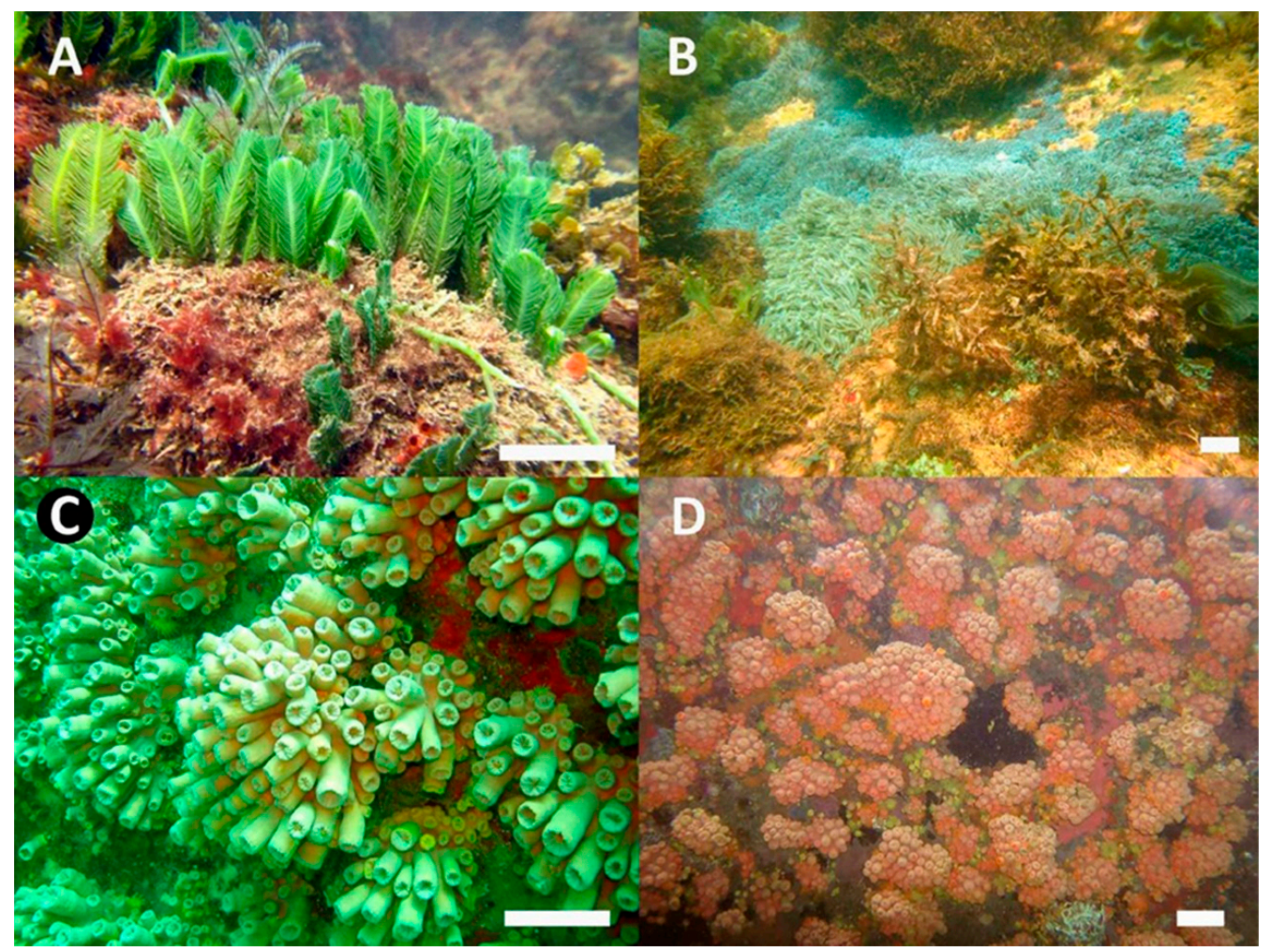

Figure 2. Alien species studied in the present work: (A) Caulerpa scalpelliformis; (B) Sansibia sp.; (C) Tubastraea tagusensis; (D) Tubastraea coccinea. 


\subsubsection{Sansibia sp. at Praia Vermelha (PV)}

Located in Angra dos Reis, in the inner part of the BIG $\left(23^{\circ} 01^{\prime} 34^{\prime \prime} \mathrm{S}, 44^{\circ} 30^{\prime} 05^{\prime \prime} \mathrm{W}\right)$, this site has calm and shallow waters, with maximum depths of rocky reefs from $4-7 \mathrm{~m}$ where a sand plain starts. The main local activities are nautical tourism and fishing. In 2017, two species of soft coral were detected on the rocky coast, Clavularia cf. viridis and Sansibia sp. Both species are of Indo-Pacific origin and have never been recorded in the Atlantic although Sansibia sp. is still little-known and has been described recently [32]. After being removed, C. viridis was eradicated at PV, however the control of Sansibia sp., which has since expanded its range [33,34], is ongoing. As all the detected species are used by aquarium hobbyists, it is highly probably that the introduction was by disposal of a domestic aquarium [33] or an in situ coral farming strategy [34] (Figure 2B).

\subsubsection{Tubastraea tagusensis at Ilha Comprida (IC)}

Located about $5 \mathrm{~km}$ off Rio de Janeiro $\left(23^{\circ} 02^{\prime} 15^{\prime \prime} \mathrm{S}, 43^{\circ} 12^{\prime} 17^{\prime \prime} \mathrm{W}\right)$, it is one of the five islands and two islets that make up the Cagarras Archipelago, a Marine Protect Area. The IC study site is positioned in the interior of the archipelago sheltered from wave action. The maximum reef depth is $40 \mathrm{~m}$ and it is impacted by eutrophication from Rio de Janeiro city as well as receiving high levels of tourism (diving and boat trips) [35]. The azooxantellated coral Tubastraea tagusensis is endemic and native to the Galapagos Archipelago where it is reported as abundant and forms an important component of the coral fauna. It was introduced into Brazil on oil platforms in the 1980s along with its congener T. coccinea [36]. Tubastraea tagusensis has also been reported in India, Palau and the Persian Gulf, though the validity of those reports has been questioned [36]. In the Cagarras Archipelago T. tagusensis was detected and manually removed in 2004 but in 2011 the species was again reported at the site [36] (Figure 2C,D).

\subsubsection{Tubastraea coccinea and T. tagusensis at Ilha de Âncora (IA)}

IA is an island located $8 \mathrm{~km}$ offshore farther northwest at Armação dos Búzios $\left(22^{\circ} 46^{\prime} 16^{\prime \prime} \mathrm{S}\right.$, $41^{\circ} 47^{\prime} 08^{\prime \prime} \mathrm{W}$ ). It is also a popular dive site in the region, with transparent, calm and shallow waters (depth $<22 \mathrm{~m}$ ). IA is subject to a seasonal upwelling of Central South Atlantic Water, characterized by higher nutrient supply (nitrate up to $18 \mu \mathrm{M}$ ) and low temperatures (down to $14^{\circ} \mathrm{C}$ ) [37]. In addition to T. tagusensis, IA has also been invaded by an AS of the same genus T. coccinea, which was first recorded there in 2011 [38]. Tubastraea coccinea has a native range throughout the tropical and sub-tropical Indo-Pacific and has invaded some Atlantic Islands, the Caribbean Sea, the Gulf of Mexico and the southwest Atlantic (Brazil) [36].

\subsection{Sampling}

We carried out quantitative surveys of the benthic communities in continuous extensions of the benthos along $50 \mathrm{~m}$ of each rocky shore in 2017 (at PB and IA in July; at IC in September) and 2018 (at PV after the invasion was detected, in December). At each site, sampling was carried out in communities under the two different invasion states. Using SCUBA and the photo-quadrat method (digital photography at 300 dpi resolution using a NIKON COOLPIX AW130 and a fixed frame), twelve $0.25 \mathrm{~m}^{2}$ sample quadrats were obtained randomly in invaded and non-invaded areas. Since at PB the hard substrate consisted of boulders within a sand matrix (discontinuous), we randomly chose four boulders with the macroalgae $C$. scalpelliformis and four without sampling. Fieldwork was conducted under research licenses INEA 005/2009 and 044/2018 and IBAMA No 02/2016 (Proc. 02001.003231/2014-02).

\subsection{Data Analysis}

2.3.1. Species Abundance Analysis

Using photo-quadrats and additional digital photography, macroscopic species were subsequently identified to the lowest possible taxonomic level. Species nomenclature 
was standardized to the World Register of Marine Species (WoRMS) database (http: //www.marinespecies.org/, accessed on 2 April 2020) [39]. The photo-quadrats were used to estimate the percentage of cover of each taxon of the sessile macrobenthos. We used 100 random points generated by the CPCe software (Coral Point Count with Excel extension) [40] for each photo quadrat, thus generating a matrix of average relative abundances of each taxon by location and invasion state. In order to investigate the differences in species diversity caused by invasion state we plotted ranking-species abundances (= dominance and diversity curves), where the x-axis corresponds to the species ranked in decreasing abundance and the $y$-axis corresponds to the relative abundances of species on a logarithmic scale.

In order to better characterize and compare communities under different invasion states, five SAD models were applied: Broken Stick, Geometric Series, Lognormal, Zipf and Mandelbrot. For the adjustment and selection of the SAD models, we used the method of maximum likelihood estimation selected through the Akaike Information Criterion (AIC) and $\triangle \mathrm{AIC} \leq 2$. AIC is a relative measure derived from the likelihood function that compares models and can be used in addition to visual inspection of the plotted data. The AIC selects the model that best fits the data by measuring the distance from the real model to the model analyzed, and the one with the lowest AIC value is considered the most appropriate, and $\triangle \mathrm{AIC} \leq 2$ values establish that the model is plausible to be used [41].

We tested the differences in communities between invasion states using the Permutational MANOVA (PERMANOVA) based on Bray-Curtis similarity measures of the square root of the percentage of cover of each taxon of the sessile macrobenthos + 1. Simpson's diversity index (1-Lambda), Margalef's diversity index (d), Shannon's ( $\left.H^{\prime}\right)$, Fisher and Equality of Pielou $\left(J^{\prime}\right)$ of each community were calculated. We also carried out this analysis on the data set from which the AS had been removed and other species standardized in the abundance matrix (the cover of AS was reassigned to the native species proportionally to their abundance) termed "AS removed". The SAD analyzes were performed in the program $R$ v3.6.0 (R Core Team 2020), and we use the 'vegan' R-package [42]. For PERMANOVA we used the statistical program PERMANOVA+ add-on for Primer v6 [43,44].

\subsubsection{Functional Diversity Analysis}

A set of 14 relevant species traits [45] (Table S1) were identified and modalities for each trait category were defined through bibliographic survey and expert consultation (Table S1). The information for each trait was ordered as binary or continuous characteristics and compiled for all species in the analyzed data sets. For mixed trait data, we used the "Cailliez" correction, which consists of adding the smallest possible constant to the distances to eliminate all negative eigenvalues [46-48]. To evaluate the impact of AS on functional characteristics of the rocky shore communities, we estimated five multidimensional indices of functional diversity (FRic: Functional richness, FEve: Functional evenness, FDiv: Functional divergence, FDis: Functional dispersion and RaoQ: Rao's quadratic entropy).

To assess patterns in the communities under different invasion states, we estimated the effect sizes in each diversity index as the response ratios (RR) to control rocky shore community differences:

$$
\mathrm{RR}=\text { (Iwith/Iwithout) }
$$

where " $\mathrm{I}$ " represents the taxonomic or functional diversity indices of rocky reef-invaded (numerator) or not-invaded (denominator) by the AS. The RR has a $>1$ or $<1$ value according to the relative increase or decrease, respectively, in the diversity index of the rocky shoreinvaded compared to the rocky shore-not-invaded. The RR is 1 when there is no difference.

In addition to comparing communities under different invasion states, we also performed the same analysis, but removed the invaders ("AS removed"), thus clarifying whether there are possible sources of variation caused only by the contribution of the AS. All functional diversity metrics were computed in the FD package $[47,48]$ of the $\mathrm{R} v 3.6 .0$ program [49]. 


\section{Results}

Over the four sites we found a total of 66 taxa of sessile macrobenthic species, 23 of which were algae, 13 sponges, four bryozoans, 18 cnidarians, three ascidians, two echinoderms, two molluscs and one crustacean (Table S2). The taxon richness was lower in invaded communities, except for PB site (Figure 3). In three of the invaded communities, the AS was/were the most abundant taxon(s), with the exception of PV where the invading soft coral Sansibia sp. was the second most abundant species in the community after the (native) alga Sargassum vulgare (Figure 3). Sessile macrobenthos assemblage cover was significantly different between invasion states in each rocky shore sites (PERMANOVA: $\mathrm{PV}, \mathrm{df}=23$; Pseudo-F $=13.016 ; p=0.001 ; \mathrm{IA}, \mathrm{df}=23$; Pseudo-F $=12.626 ; p=0.001 ; \mathrm{CI}$, $\mathrm{df}=23 ;$ Pseudo-F = 11.271; $p=0.001 ; \mathrm{PB}, \mathrm{df}=7$; Pseudo-F = 2.932; $p=0.026$ ).
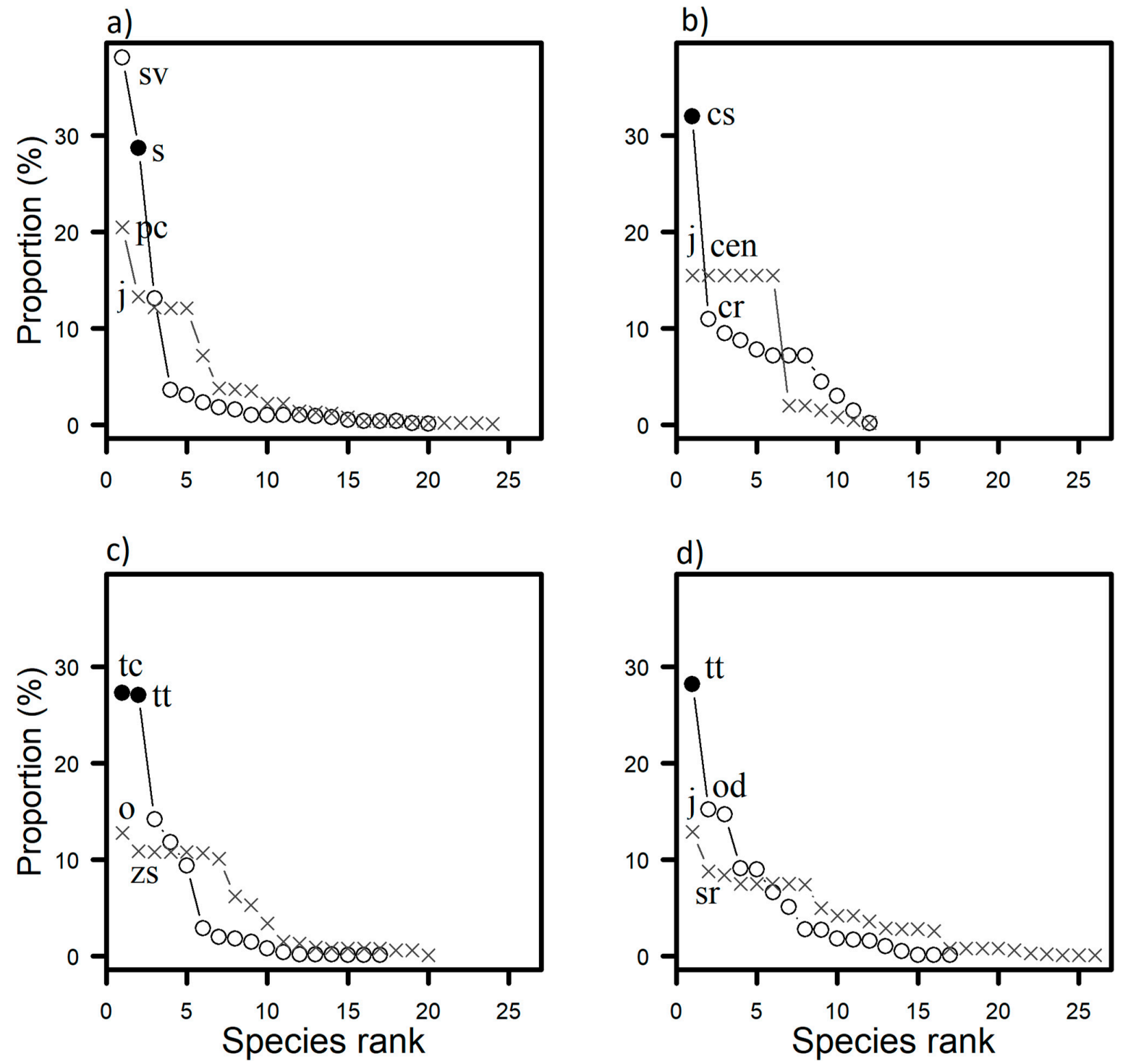

Figure 3. Species rank abundance plots for benthic taxons in four invaded communities represented by the symbol $\bigcirc$ and four not-invaded communities represented by the symbol $\times$ on marine tropical rocky shores along the coast of the State of Rio de Janeiro, Brazil at (a) Praia Vermelha (PV), (b) Praia da Baleia (PB), (c) Ilha de Âncora (IA) and (d) Ilha Comprida (IC). AS are represented by the symbol $\bullet$. sv $=$ Sargassum vulgare, $\mathrm{s}=$ Sansibia sp., $\mathrm{pc}=$ Palythoa caribaeorum, $\mathrm{j}=$ Jania adhaerens, $\mathrm{o}=$ Echinometra lucunter, $\mathrm{cs}=$ Caulerpa scalpelliformis, $\mathrm{cen}=$ Centroceras $\mathrm{sp} ., \mathrm{c}=$ Caulerpa racemosa, $\mathrm{tt}=$ Tubastraea tagusensis, tc $=$ Tubastraea coccinea, $\mathrm{zs}=$ Zoanthus sociatus, od = Obelia dichotoma, $\mathrm{sr}=$ Scopalina ruetzleri . 
According to the diversity indices, not-invaded communities had greater diversity than invaded ones, except for the PB site that had similar values in both communities. Under the AS removed scenario, there was no change in the general pattern of the results of the taxonomic diversity over sites. PB once again stood out in this respect as the Simpson, Fisher and Shannon indices, which were not different between invasion states but were reduced under the AS removed scenario. According to these indices, the diversity was greater in the not-invaded communities and under the AS removed scenario it increased for the three other sites (Figure 4) (Table S3).
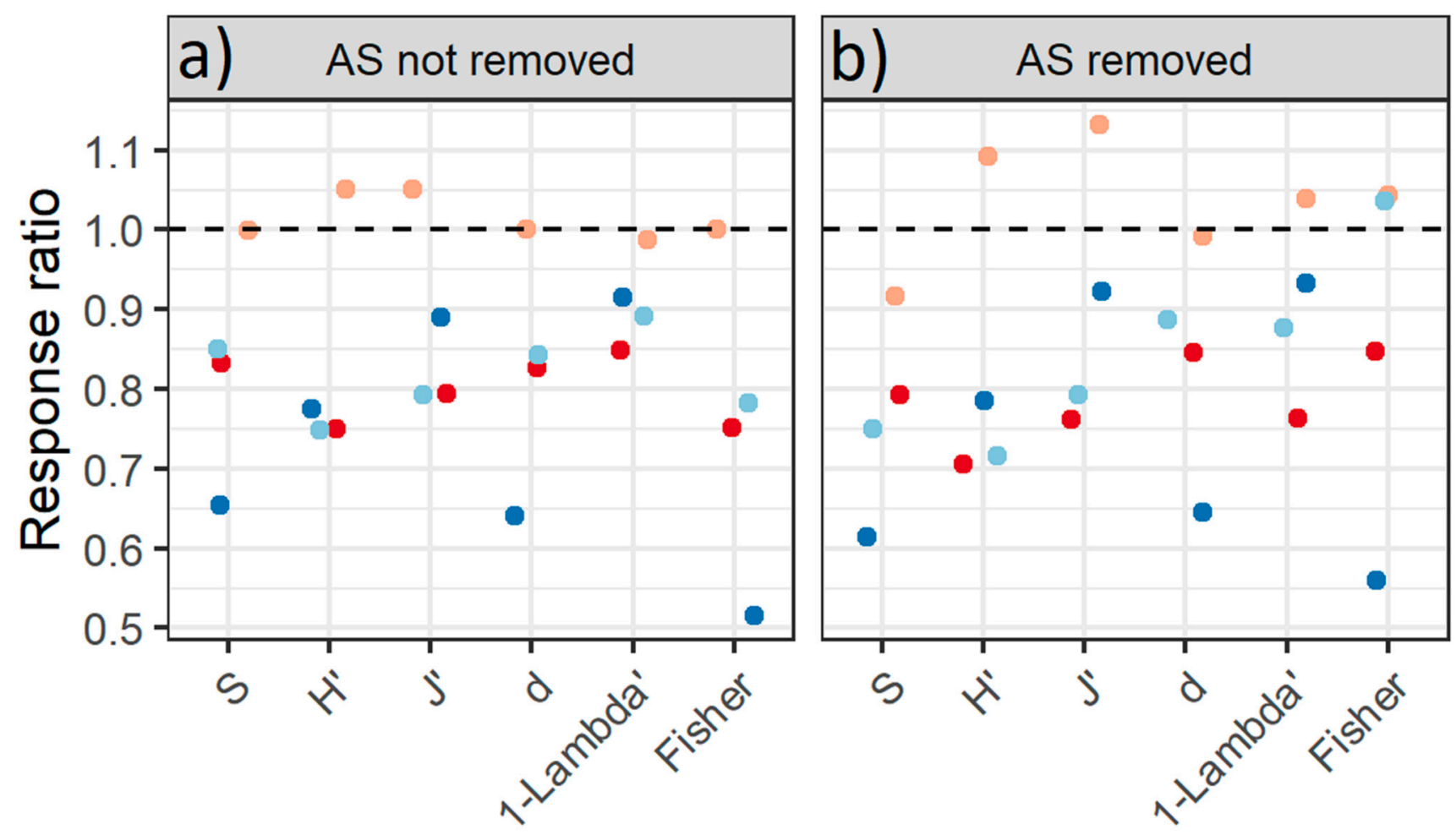

Figure 4. Response ratio between the taxonomy diversity indices $\left(\mathrm{S}, \mathrm{H}^{\prime}, \mathrm{J}\right.$ ', $\mathrm{d}, 1$-Lambda' and Fisher) of the invaded communities (numerator) and not-invaded communities (denominator) under two scenarios: (a)Alien species (AS) not removed and (b) AS removed on marine tropical rocky shores along the coast of the State of Rio de Janeiro, Brazil at Praia Vermelha (red), Praia da Baleia (orange); Ilha de Âncora (light blue) and Ilha Comprida (dark blue).

Considering the smallest AIC and depending on the invasive state or NS removed scenario all five models were retained, although the Zipf model least so (Table 1). The geometric-series model was the most ubiquitously retained, best adjusting to all communities, regardless of the invasion state or NS removal scenario, with the exception of the invaded community at PB and under the NS removal scenario from the PV community. The broken-stick model showed the best fit to invaded communities, even under the removal scenario, the exception being PV where the broken stick model was not retained for the invaded and NS removed communities (Table 1).

Table 1. Models of rank abundance by site and situation with and without nonnative species (NIS) retained with better adjustments based on the lowest $\mathrm{AIC}$ criteria and $\triangle \mathrm{AIC} \leq 2$. Bs = Broken-stick; gs = Geometric Series; $\ln =$ Log-normal; $\mathrm{z}=$ Zipf e $\mathrm{m}=$ = Madelbrot.

\begin{tabular}{cccc}
\hline Site & Not-Invaded & Invaded & AS Removed \\
\hline PV & bs, gs & gs, $\mathrm{m}$ & $\mathrm{z}, \mathrm{m}$ \\
PB & gs, ln, $\mathrm{g}$ & $\mathrm{bs}, \ln , \mathrm{z}$ & $\mathrm{gs}, \ln$ \\
IA & gs, ln, $\mathrm{m}$ & $\mathrm{bs}, \mathrm{gs}$ & $\mathrm{bs}, \mathrm{gs}$ \\
IC & $\mathrm{gs}, \ln$ & $\mathrm{bs}, \mathrm{gs}$ & $\mathrm{bs}, \mathrm{gs}$ \\
\hline
\end{tabular}


Regarding the traits, the scores used for each trait modality in this study are presented in Table S4. The values of the functional dispersion (FDis), functional divergence (FDiv) and Rao quadratic entropy (RaoQ) index were lower in the invaded communities. The range of FDis and RaoQ was between $>0.7$ and $<1.0$, which represented a reduction of $3 \%$ to $29 \%$ in these indices in the invaded communities compared to the not-invaded communities. However, when considering AS removed, the results of these indices were not as consistent and indicated an increase of up to $20 \%$ in FDis and RaoQ in the invaded community compared to the not-invaded community of the PB site. Functional richness (FRic) was $\leq 0.4$ in invaded communities and AS removed, which means a $\geq 60 \%$ reduction in FRic in the invaded community compared to not-invaded communities. In AS removed at $\mathrm{PB}$, the indices that quantify the functional dispersion (FDis and RaoQ) increased and showed higher values than in not-invaded communities. The FRic index was lower in invaded communities and it was also the functional diversity index that best reflected the difference in the functional attributes in the invasion state. FDiv results also varied between sites, showing an increase or decrease of approximately $10 \%$. The not-invaded community at PB had higher FDiv, FDis and FEve indexes than the invaded community, and the NS removed scenario resulted in an increase in the RaoQ index. The same variation in FEve index was observed in PV, higher even than in the invaded community, showing an increase of approximately $30 \%$ when AS were removed. In IA and IC sites, FEve index showed a reduction of up to $20 \%$ in the invaded community compared to the non-invaded one (Figure 5).
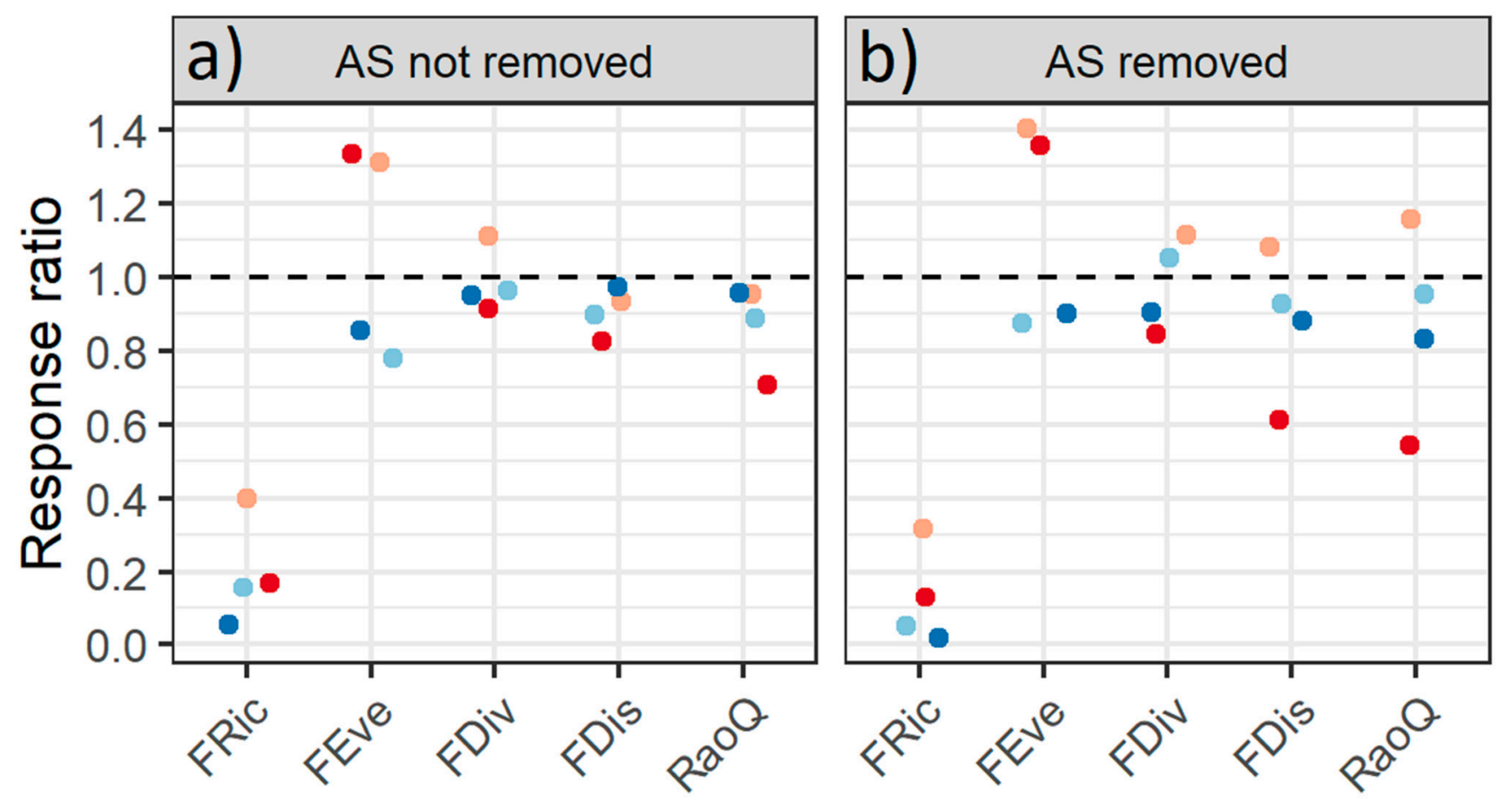

Figure 5. Response ratio between the functional diversity indices (FRic, FEve, FDiv, FDis and RaoQ) of the invaded communities (numerator) and not-invaded communities (denominator) in two scenarios: (a) Alien species (AS) not removed and (b) AS removed on marine tropical rocky shores along the coast of the State of Rio de Janeiro, Brazil at Praia Vermelha (red), Praia da Baleia (orange); Ilha de Âncora (light blue) and Ilha Comprida (dark blue).

\section{Discussion}

Our study provides evidence of the impact of different alien species (AS), not only in structure but also in function, in different invaded tropical rocky shore communities in the southwest Atlantic. Although more is known about effects on community species abundance and diversity, functional diversity analysis is not commonly applied. 
We tested different parameters to measure the effect of an AS on invaded communities, and although the rank-abundance plots make it possible to observe the greater abundance of AS in relation to the other species in the invaded communities and the greater equitability in not-invaded communities, we consider that point-paired species abundance distribution (SAD) models are not the most sensitive tool for detecting the effects of AS. The geometric series model had the best fit for most communities regardless of the presence or absence of a AS or in AS removed treatments. Geometric series reflect a relationship between the abundance of a species and its constant predecessor, therefore, its plot representation in the rank-abundance is a steep line, which implies an assembly with high dominance [50,51]. The broken-stick model was better adjusted to invaded communities. The exception was PV, recently invaded (2017) by the soft coral Sansibia sp. The uniform abundance predicted by the broken-stick model does not seem to match the values of the diversity indexes with invaded communities. Still, the curves fitted to the broken-stick and log-normal models are less steep and represent relatively high uniformity in the community [52,53].

In three of the invaded communities studied here, AS were the most abundant species. Different studies have demonstrated that an increase in the abundance of NS after invasion events in aquatic environments is usual and that there is consequent dominance in the invaded areas [54-57]. Invasive corals T. coccinea and T. tagusensis have been known to increase their distribution in Brazilian waters since their introduction in the late 1980s [35]. The abundance of Tubastraea spp. increased by up to $76 \%$ in just one year in the Baía da Ilha Grande (BIG) [58]. Similarly, there was a change in the rocky and sandy substrates at Praia da Baleia (PB) after the introduction of $C$. scalpelliformis, which became dominant over the alga S. vulgare [29]. Our results show that after 17 years the invasive algae C. scalpelliformis remains the most abundant species in the invaded area.

At Praia Vermelha (PV), the invasive soft coral Sansibia sp. was the second-most abundant species, second only to the alga $S$. vulgare. Among all the invaded communities analyzed in the present study, PV represents the most recent invasion (2017) and the invasive soft coral still seems to be increasing in abundance over the years. Sansibia sp. was the third-most abundant species in PV in 2017 [33], but was second in our study; this change in local diversity suggests that the invading soft coral Sansibia sp. may also become the most abundant species at PV in the future.

As expected, the diversity indexes used in the present study showed that diversity was higher in not-invaded communities than in invaded communities, and the same pattern was repeated in AS removed treatments. Our results suggest that the impact of AS varies in proportion to the species that already exist in the community and that AS effects the invaded community not only by representing one more species in the community, but by considerably impacting evenness (the relative abundance of the other species). However, at $\mathrm{PB}$, Shannon's diversity index $\left(\mathrm{H}^{\prime}\right)$ and Pielou's Equability indice $\left(\mathrm{J}^{\prime}\right)$ were higher in the invaded community while the other indices showed similar values in invaded and notinvaded communities. Under AS removed, Fisher, $\mathrm{H}$ 'and J' indices had the highest values compared to other situations. As well as the fact that invasive algae C. scalpelliformis is by far the most abundant species in the community, this is thought to be because there were fewest native species at this site, so the richness aspect of diversity was more important (increased due to the presence of the invader). This was the exception to the rule as at PV, Ilha de Âncora (IA) and Ilha Comprida (IC), $\mathrm{H}^{\prime}$ was between $20 \%$ and $30 \%$ lower in invaded communities. Fisher's diversity was between $20 \%$ and $50 \%$ lower in invaded communities.

1-Lambda and $\mathrm{H}^{\prime}$ provide complementary information on community diversity, while the first emphasizes the uniformity component, the second is influenced by functional richness (FRic) [9,59]. According to the hypothesis of biotic resistance, the higher biodiversity of an ecosystem can make it more resistant to invasion [19,60-63]. The reduced diversity found at three of the four (native species richer) sites is not inconsistent with the hypothesis of biotic resistance, in that successful invasions would explicitly imply stronger competitive interactions between AS and natives. The Empty Niche Hypotheses would 
be consistent with the invasion of the algae $C$. scalpelliformis at $\mathrm{PB}$, especially seeing as this alga was sufficiently plastic with regard to substratum use such that it was observed to grow in nearby (unvegetated) sediment as well as on the rocky substrate we studied, so clearly it could occupy an empty niche space. The rocky shore nearby the rock-sand interface typically has higher sediment cover, which may be a niche little exploited by the native benthos.

Functional diversity analysis is a tool that considers that all species are not equivalent, and perform different functions in the ecosystem [27,64]. This type of analysis has not commonly been applied to invaded marine environments and the amount of effort dedicated to studies to understand and predict marine invasions is not consistent when compared to studies carried out on terrestrial systems $[65,66]$. Functional wealth (FRic) was lower in invaded communities and in NS removed communities. It is possible that the NS in the present study have redundant functional attributes, since FRic measures the portion of the functional space filled by the species with the most extreme characteristic values [22]. The functional evenness index (FEve) was higher in the invaded communities at PV and PB, and this shows how regularly the abundances of species are distributed in the functional space, suggesting a more regular distribution of the attributes in the invaded communities [67]. This is consistent with the observations above regarding degrees of competition in more recently invaded (PV) and lower richness/empty niche (PB) communities. The introduction of the green algae C. salpeliformis incorporates attributes similar to those of the most abundant species in the community, since in the NS removed treatment, the values of the functional dispersion index increased, suggesting that before removal, the species were closer to the centroid defined by all traces of species in the community, with lower values of FDis and RaoQ compared to not-invaded communities.

Our results provide evidence that species identity is more important than species richness in determining the number and biomass of NS, similar to the results found in other studies for terrestrial plants [68]. Invasions by non-native macroalgae are likely to cause biotic homogenization and have an overall negative effect on their competitors, spatially monopolizing the habitat and resulting in the reduction of abundance and biomass of native macroalgae $[12,69,70]$. The few studies that explore the relationship between functional diversity and invasion in seaweed communities have focused on the availability of resources and the success of invasion [68,71,72]. Functional traits in macroalgae communities can also influence the availability of resources (i.e., light and substrate) and have inhibitory effects on new colonizers [68]. The availability of resources can vary according to functional diversity, as when functional diversity is high the availability of resources (i.e., photosynthetically active radiation) is low [72]. However, functional diversity indices between communities invaded and not-invaded by Carpobrotus spp. showed similar results to the present study [73], suggesting that the low functional diversity in the invaded communities reveals a functional homogenization within the community.

We consider the taxonomic diversity and functional diversity indices to be useful tools for identifying processes that determine the biological diversity of invaded communities, as they seem to obey a pattern that reflects the greatest diversity in communities not-invaded by IS. Additional information on the impacts of IS on ecosystems is crucial for formulating conservation goals for specific species or habitats, and a thorough understanding of their role in the functioning of the ecosystem and the consequent provision of ecosystem services is needed in order to better define strategies for control and eradication of an invaded area [6,74]. We studied consolidated or consolidating invasions, but another aspect of using these methods that would be enlightening and informative would be to investigate the temporal element of changes that occur in communities during a boombust invasion cycle typical of some species [16]. Thus, we recommend further studies that consider not only taxonomic diversity, but also the differences in the roles played by species and their contributions to the relationships of diversity and functioning of invaded marine ecosystems. 
Supplementary Materials: The following are available online at https:/ / www.mdpi.com/article/ 10.3390/d13080353/s1, Table S1: Trait categories of species and their modalities considered in this study. Table S2: Major space-occupying taxa/functional groups, their percentage cover (\%) in invaded and not-invaded communities on marine rocky shores along the coast of the state of Rio de Janeiro, Brazil. Table S3: Values of the taxonomic diversity index and functional diversity index. Table S4: Scores used for each trait modality in this study.

Author Contributions: Conceptualization, L.M.P.-T., V.N.-L. and J.C.C.; Data curation, L.M.P.-T.; Formal analysis, L.M.P.-T. and V.N.-L.; Funding acquisition, J.C.C.; Investigation, L.M.P.-T. and V.N.-L.; Methodology, V.N.-L. and J.C.C.; Project administration, J.C.C.; Supervision, V.N.-L. and J.C.C.; Visualization, V.N.-L.; Writing-original draft, L.M.P.-T.; Writing-review \& editing, V.N.-L. and J.C.C. All authors have read and agreed to the published version of the manuscript.

Funding: This research was funded by Fundação Carlos Chagas Filho de Amparo à Pesquisa do Estado do Rio de Janeiro, grant numbers E-26/010.003031/2014 and E26/203.002/2017, Conselho Nacional de Desenvolvimento Científico e Tecnológico grant number 305924/2018-4 and Brazilian Biodiversity Fund (FUNBIO) Contract number 011/2017 (BrBio -Projeto Coral-Sol).

Data Availability Statement: The data presented in this study are available in Supplementary Materials.

Acknowledgments: This work was supported by Fundação Carlos Chagas Filho de Amparo à Pesquisa do Estado do Rio de Janeiro (JCC, FAPERJ E-26/010.003031/2014 and E26/203.002/2017) and Conselho Nacional de Desenvolvimento Científico e Tecnológico (JCC, CNPq- 305924/20184) and received support for fieldwork logistics and equipment from the Brazilian Institute for Biodiversity (BrBio) as part of the Coral-sol Project funded through the Commitment to Conduct Adjustment Agreement signed by Chevron Brazil with the Brazilian Federal Prosecution Service (Ministério Público Federal), with implementation by the Brazilian Biodiversity Fund (FUNBIO). LMPT acknowledges Coordenação de Aperfeiçoamento de Pessoal de Nível Superior (CAPES) that provided a PhD scholarship. VNL acknowledges a Teaching Support Scholarship (PAPD-UERJ/2019). We thank Amanda Guilherme, Augusto Machado, Bruno Masi, Herick Simas, Edson Faria, Katia Capel, Marcello Mantellato, Vanessa Bettcher and Vinícius Kerr for their support in the field. Thanks to Anastasija Zaiko and the Global Hotspots for Marine Bioinvasions group members for providing and allowing us to use the traits list. This article is no. 48 from the Projeto Coral-Sol.

Conflicts of Interest: The authors declare no conflict of interest.

\section{References}

1. Carlton, J.T. Bioinvasion ecology: Assessing invasion impact and scale. In Invasive Aquatic Species of Europe. Distribution, Impacts and Management, 1st ed.; Leppäkoski, E., Gollasch, S., Olenin, S., Eds.; Kluwer Academic Publishers: Dordrecht, The Netherlands, 2002; pp. 7-19.

2. Ruiz, G.M.; Carlton, J.T.; Grosholz, E.D.; Hines, A.H. Global invasions of marine and estuarine habitats by non-indigenous species: Mechanisms, extent, and consequences. Am. Zool. 1997, 37, 621-632. [CrossRef]

3. Teixeira, L.M.; Creed, J.C. A decade on: An updated assessment of the status of marine non-indigenous species in Brazil. Aquat. Invasions 2020, 15, 30-43. [CrossRef]

4. Bailey, S.A.; Brown, L.; Campbell, M.L.; Canning-Clode, J.; Carlton, J.T.; Castro, N.; Chainho, P.; Chan, F.T.; Creed, J.C.; Curd, A.; et al. Trends in the detection of aquatic non-indigenous species across global marine, estuarine and freshwater ecosystems: A 50-year perspective. Divers. Distrib. 2020, 26, 1780-1797. [CrossRef]

5. Occhipinti-Ambrogi, A.; Savini, D. Biological invasions as a component of global change in stressed marine ecosystems. Mar. Pollut. Bull. 2003, 46, 542-551. [CrossRef]

6. Giakoumi, S.; Guilhaumon, F.; Kark, S.; Terlizzi, A.; Claudet, J.; Felline, S.; Cerrano, C.; Coll, M.; Danovaro, R.; Fraschetti, S.; et al. Space invaders; biological invasions in marine conservation planning. Divers. Distrib. 2016, 22, 1220-1231. [CrossRef]

7. Gallardo, B.; Clavero, M.; Sánchez, M.I.; Vilà, M. Global ecological impacts of invasive species in aquatic ecosystems. Glob. Chang. Biol. 2016, 22, 151-163. [CrossRef]

8. Hansen, G.J.; Vander Zanden, M.J.; Blum, M.J.; Clayton, M.K.; Hain, E.F.; Hauxwell, J.; Izzo, M.; Kornis, M.S.; McIntyre, P.B.; Mikulyuk, A.; et al. Commonly rare and rarely common: Comparing population abundance of invasive and native aquatic species. PLOS ONE 2013, 8, e77415. [CrossRef]

9. Magurran, A.E. Measuring Biological Diversity, 1st ed.; Wiley-Blackwell: Carleton, Australia, 2003; pp. $18-71$.

10. Bremner, J.; Rogers, S.I.; Frid, C.L.J. Assessing functional diversity in marine benthic ecosystems: A comparison of approaches. Mar. Ecol. Prog. Ser. 2003, 254, 11-25. [CrossRef]

11. Bremner, J.; Rogers, S.I.; Frid, C.L.J. Methods for describing ecological functioning of marine benthic assemblages using biological traits analysis (BTA). Ecol. Indic. 2006, 6, 609-622. [CrossRef] 
12. Thomsen, M.S.; Olden, J.D.; Wernberg, T.; Griffin, J.N.; Silliman, B.R. A broad framework to organize and compare ecological invasion impacts. Environ. Res. 2011, 111, 899-908. [CrossRef] [PubMed]

13. MacArthur, R. Species packing and competitive equilibrium for many species. Theor. Popul. Biol. 1970, 1, 1-11. [CrossRef]

14. Emery, S.M. Limiting similarity between invaders and dominant species in herbaceous plant communities? J. Ecol. 2007, 95, 1027-1035. [CrossRef]

15. Strayer, D.L.; Eviner, V.T.; Jeschke, J.M.; Pace, M.L. Understanding the long-term effects of species invasions. Trends Ecol. Evol. 2006, 21, 645-651. [CrossRef] [PubMed]

16. Strayer, D.L.; D'Antonio, C.M.; Essl, F.; Fowler, M.S.; Geist, J.; Hilt, S.; Jarić, I.; Jöhnk, K.; Jones, C.G.; Lambin, X.; et al. Boom-bust dynamics in biological invasions: Towards an improved application of the concept. Ecol. Lett. 2017, 20, 1337-1350. [CrossRef]

17. Catford, J.A.; Jansson, R.; Nilsson, C. Reducing redundancy in invasion ecology by integrating hypotheses into a single theoretical framework. Divers. Distrib. 2009, 15, 22-40. [CrossRef]

18. Hejda, M.; Bello, F. Impact of plant invasions on functional diversity in the vegetation of Central Europe. J. Veg. Sci. 2013, 24, 890-897. [CrossRef]

19. Elton, C.S. The Ecology of Invasions by Animals and Plants, 2nd ed.; Springer Nature: Oxford, UK, 1958; pp. 125-174.

20. Riva, E.G.; Godoy, O.; Castro-Díez, P.; Gutiérrez-Cánovas, C.; Vilà, M. Functional and phylogenetic consequences of plant invasion for coastal native communities. J. Veg. Sci. 2019, 30, 510-520. [CrossRef]

21. Shuai, F.; Lek, S.; Li, X.; Zhao, T. Biological invasions undermine the functional diversity of fish community in a large subtropical river. Biol. Invasions 2018, 20, 2981-2996. [CrossRef]

22. Toussaint, A.; Charpin, N.; Beauchard, O.; Grenouillet, G.; Oberdorff, T.; Tedesco, P.A.; Brosse, S.; Villéger, S. Non-native species led to marked shifts in functional diversity of the world freshwater fish faunas. Ecol. Lett. 2018, 21, 1649-1659. [CrossRef]

23. Milardi, M.; Gavioli, A.; Soininen, J.; Castaldelli, G. Exotic species invasions undermine regional functional diversity of freshwater fish. Sci. Rep. 2019, 9, 1-10. [CrossRef]

24. Matsuzaki, S.I.S.; Sasaki, T.; Akasaka, M. Consequences of the introduction of exotic and translocated species and future extirpations on the functional diversity of freshwater fish assemblages. Glob. Ecol. Biogeogr. 2013, 22, 1071-1082. [CrossRef]

25. Rosindell, J.; Cornell, S.J. Universal scaling of species-abundance distributions across multiple scales. Oikos 2013, 122, 1101-1111. [CrossRef]

26. Mason, N.W.; de Bello, F.; Mouillot, D.; Pavoine, S.; Dray, S. A guide for using functional diversity indices to reveal changes in assembly processes along ecological gradients. J. Veg. Sci. 2013, 24, 794-806. [CrossRef]

27. Villéger, S.; Mason, N.W.; Mouillot, D. New multidimensional functional diversity indices for a multifaceted framework in functional ecology. Ecology 2008, 89, 2290-2301. [CrossRef]

28. Fried, G.; Carboni, M.; Mahaut, L.; Violle, C. Functional traits modulate plant community responses to alien plant invasion. Perspect. Plant. Ecol. Evol. Syst. 2019, 37, 53-63. [CrossRef]

29. Falcão, C.; Széchy, M.T.M. Changes in shallow phytobenthic assemblages in southeastern Brazil, following the replacement of Sargassum vulgare (Phaeophyta) by Caulerpa scalpelliformis (Chlorophyta). Bot Mar. 2005, 48, 208-217. [CrossRef]

30. Lopes, R.M.C.; Pombo, L.; Cunha, V.B.; Rimoldi, D. Informe Sobre as Espécies Exóticas Invasoras Marinhas no Brasil, 1st ed.; Ministério do Meio Ambiente-Secretaria de Biodiversidade e Florestas: Brasília, Brazil, 2009; p. 440.

31. Vasconcelos, M.A.; Schubart, C.L.Q.; Széchy, M.T.M.D. Temporal variation in vegetative development of Caulerpa scalpelliformis (Chlorophyta) from Baleia beach, Ilha Grande bay (Rio de Janeiro, brazil). Braz. J. Oceanogr. 2011, 59, 145-152. [CrossRef]

32. Alderslade, P. Four new genera of soft corals (Coelenterata: Octocorallia), with notes on the classification of some established taxa. Zool. Meded. Leiden. 2000, 74, 237-249.

33. Mantelatto, M.C.; Silva, A.G.; Santos Louzada, T.; McFadden, C.S.; Creed, J.C. Invasion of aquarium origin soft corals on a tropical rocky reef in the southwest Atlantic, Brazil. Mar. Pollut. Bull. 2018, 130, 84-94. [CrossRef] [PubMed]

34. Carpinelli, Á.N.; Cordeiro, R.T.S.; Neves, L.M.; Moura, R.L.; Kitahara, M.V. Erythropodium caribaeorum (Duchassaing and Michelotti, 1860) (Cnidaria: Alcyonacea), an additional alien coral in the Southwestern Atlantic. Zootaxa 2020, 4822, 175-190. [CrossRef] [PubMed]

35. Creed, J.C.; Casares, F.A.; Oigman-Pszczol, S.S.; Masi, B.P. Multi-site experiments demonstrate that control of invasive corals (Tubastraea spp.) by manual removal is effective. Ocean. Coast. Manag. 2020, 207, 105616. [CrossRef]

36. Creed, J.C.; Fenner, D.; Sammarco, P.; Cairns, S.; Capel, K.; Junqueira, A.O.; Cruz, I.; Miranda, R.J.; Carlos-Junior, L.; Mantelatto, M.C.; et al. The invasion of the azooxanthellate coral Tubastraea (Scleractinia: Dendrophylliidae) throughout the world: History, pathways and vectors. Biol. Invasions 2017, 19, 283-305. [CrossRef]

37. Coelho-Souza, S.A.; López, M.S.; Guimarães, J.R.D.; Coutinho, R.; Candella, R.N. Biophysical interactions in the Cabo Frio upwelling system, Southeastern Brazil. Braz. J. Oceanogr. 2012, 60, 353-365. [CrossRef]

38. Santos, H.S.; Silva, F.G.C.; Masi, B.P.; Fleury, B.G.; Creed, J.C. Environmental matching used to predict range expansion of two invasive corals (Tubastraea spp.). Mar. Pollut. Bull. 2019, 145, 587-594. [CrossRef] [PubMed]

39. World Register of Marine Species: WoRMS. Available online: https:/ /www.marinespecies.org/ (accessed on 2 April 2020).

40. Kohler, K.E.; Gill, S.M. Coral Point Count with Excel extensions (CPCe): A visual basic program for the determination of coral and substrate coverage using random point count methodology. Comput. Geosci. 2006, 32, 1259-1269. [CrossRef]

41. Burnham, K.P.; Anderson, D.R. Multimodel inference: Understanding AIC and BIC in model selection. Sociol. Methods Res. 2004, 33, 261-304. [CrossRef] 
42. Oksanen, J.; Blanchet, F.G.; Kindt, R.; Legendre, P.; Minchin, P.R.; O’hara, R.B.; Simpson, G.L.; Solymos, P.; Stevens, M.H.H.; Szoecs, E.; et al. Package 'vegan'. Community Ecology Package, Version 2. 2013. Available online: https://CRAN.R-project.org/ package=vegan (accessed on 31 July 2020).

43. Clarke, K.R.; Gorley, R.N. PRIMER v6: User Manual/Tutorial, Primer E: Plymouth, 1st ed.; Plymouth Marine Laboratory: Plymouth, UK, 2006.

44. Anderson, M.J.; Clarke, K.R.; Gorley, R.N. PERMANOVA+ for Primer. Guide to Software and Statistical Methods; University of Auckland and PRIMER-E Ltd.: Plymouth, UK, 2008.

45. Zaiko, A.; Cardeccia, A.; Carlton, J.T.; Clark, G.; Creed, J.; Davidson, I.; Floerl, O.; Galil, B.; Grosholz, E.; Hopkins, G.A.; et al. Structural and Functional Shifts Associated with Increased Invasions in Benthic Marine Communities: Spatial-Temporal Insights and Challenges; Anastasija.Zaiko@cawthron.org.nz, Private Bag 2, Nelson 7042, New Zealand, 2021 (manuscript in preparation).

46. Cailliez, F. The analytical solution of the additive constant problem. Psychometrika 1983, 48, 305-308. [CrossRef]

47. Laliberté, E.; Legendre, P.; Shipley, B.; Laliberté, M.E. Package 'FD': Measuring Functional Diversity from Multiple Traits, and other Tools for Functional Ecology; R Foundation for Statistical Computing: Vienna, Austria, 2014; pp. 1-17.

48. Laliberté, E.; Legendre, P. A distance-based framework for measuring functional diversity from multiple traits. Ecology 2010, 91, 299-305. [CrossRef] [PubMed]

49. R Core Team. R: A Language and Environment for Statistical Computing; R Foundation for Statistical Computing: Vienna, Austria, 2013; Available online: https:/ / www.R-project.org/ (accessed on 9 June 2020).

50. Magurran, A.E. Ecological Diversity and its Measurement, 1st ed.; Princeton University Press: Princeton, New Jersey, USA, 1988; pp. 7-46.

51. Magurran, A.E. Species abundance distributions over time. Ecol. Lett. 2007, 10, 347-354. [CrossRef]

52. McGill, B.J.; Etienne, R.S.; Gray, J.S.; Alonso, D.; Anderson, M.J.; Benecha, H.K.; Dornelas, M.; Enquist, B.J.; Green, J.L.; He, F.; et al. Species abundance distributions: Moving beyond single prediction theories to integration within an ecological framework. Ecol. Lett. 2007, 10, 995-1015. [CrossRef] [PubMed]

53. Fattorini, S. A simple method to fit geometric series and broken stick models in community ecology and island biogeography. Acta Oecol. 2005, 28, 199-205. [CrossRef]

54. Meinesz, A.; Belsher, T.; Thibaut, T.; Antolic, B.; Mustapha, K.B.; Boudouresque, C.F.; Chiaverini, D.; Cinelli, F.; Cottalorda, J.; Djellouli, A.; et al. The introduced green alga Caulerpa taxifolia continues to spread in the Mediterranean. Biol. Invasions 2001, 3, 201-210. [CrossRef]

55. Piazzi, L.; Cinelli, F. Distribution and dominance of two introduced turf-forming macroalgae on the coast of Tuscany, Italy, northwestern Mediterranean Sea in relation to different habitats and sedimentation. Bot. Mar. 2001, 44, 509-520. [CrossRef]

56. Branch, G.M.; Steffani, C.N. Can we predict the effects of alien species? A case-history of the invasion of South Africa by Mytilus galloprovincialis (Lamarck). J. Exp. Mar. Biol. Ecol. 2004, 300, 189-215. [CrossRef]

57. Zabin, C.J.; Altieri, A. A Hawaiian limpet facilitates recruitment of a competitively dominant invasive barnacle. Mar. Ecol. Prog. Ser. 2007, 337, 175-185. [CrossRef]

58. Lages, B.G.; Fleury, B.G.; Menegola, C.; Creed, J.C. Change in tropical rocky shore communities due to an alien coral invasion. Mar. Ecol. Prog. Ser. 2011, 438, 85-96. [CrossRef]

59. Nagendra, H. Opposite trends in response for the Shannon and Simpson indices of landscape diversity. Appl. Geogr. 2002, 22, 175-186. [CrossRef]

60. Stachowicz, J.J.; Fried, H.; Osman, R.W.; Whitlatch, R.B. Biodiversity, invasion resistance, and marine ecosystem function: Reconciling pattern and process. Ecology 2002, 83, 2575-2590. [CrossRef]

61. Kennedy, T.A.; Naeem, S.; Howe, K.M.; Knops, J.M.; Tilman, D.; Reich, P. Biodiversity as a barrier to ecological invasion. Nature 2002, 417, 636-638. [CrossRef]

62. Fridley, J.D.; Stachowicz, J.J.; Naeem, S.; Sax, D.F.; Seabloom, E.W.; Smith, M.D.; Stohlgren, T.J.; Tilman, D.; Holle, B.V. The invasion paradox: Reconciling pattern and process in species invasions. Ecology 2007, 88, 3-17. [CrossRef]

63. Kimbro, D.L.; Cheng, B.S.; Grosholz, E.D. Biotic resistance in marine environments. Ecol. Lett. 2013, 16, 821-833. [CrossRef]

64. Guilhaumon, F.; Albouy, C.; Claudet, J.; Velez, L.; Ben Rais Lasram, F.; Tomasini, J.A.; Douzery, E.J.P.; Meynard, C.N.; Mouquet, N.; Troussellier, M.; et al. Representing taxonomic, phylogenetic and functional diversity: New challenges for Mediterranean marine-protected areas. Divers. Distrib. 2015, 21, 175-187. [CrossRef]

65. Arenas, F.; Sánchez, I.; Hawkins, S.J.; Jenkins, S.R. The invasibility of marine algal assemblages: Role of functional diversity and identity. Ecology 2006, 87, 2851-2861. [CrossRef]

66. Chan, F.T.; Briski, E. An overview of recent research in marine biological invasions. Mar. Biol. 2017, 164, 121. [CrossRef] [PubMed]

67. Mouchet, M.A.; Villéger, S.; Mason, N.W.; Mouillot, D. Functional diversity measures: An overview of their redundancy and their ability to discriminate community assembly rules. Funct. Ecol. 2010, 24, 867-876. [CrossRef]

68. Crawley, M.J.; Brown, S.L.; Heard, M.S.; Edwards, G.R. Invasion-resistance in experimental grassland communities: Species richness or species identity? Ecol. Lett. 1999, 2, 140-148. [CrossRef]

69. Olden, J.D.; Rooney, T.P. On defining and quantifying biotic homogenization. Glob. Ecol. Biogeogr. 2006, 15, 113-120. [CrossRef]

70. Schaffelke, B.; Hewitt, C.L. Impacts of introduced seaweeds. Bot. Mar. 2007, 50, 397-417. [CrossRef]

71. Britton-Simmons, K.H. Functional group diversity, resource preemption and the genesis of invasion resistance in a community of marine algae. Oikos 2006, 113, 395-401. [CrossRef] 
72. Vaz-Pinto, F.; Olabarria, C.; Arenas, F. Propagule pressure and functional diversity: Interactive effects on a macroalgal invasion process. Mar. Ecol. Prog. Ser. 2012, 471, 51-60. [CrossRef]

73. Castro-Díez, P.; Pauchard, A.; Traveset, A.; Vilà, M. Linking the impacts of plant invasion on community functional structure and ecosystem properties. J. Veg. Sci. 2016, 27, 1233-1242. [CrossRef]

74. Mačić, V.; Albano, P.G.; Almpanidou, V.; Claudet, J.; Corrales, X.; Essl, F.; Evagelopoulos, A.; Giovos, I.; Jimenez, C.; Kark, S.; et al. Biological invasions in conservation planning: A global systematic review. Front. Mar. Sci. 2018, 5, 178. [CrossRef] 